\title{
Total mercury in rice plant (Oryza sativa) collected from Sekinchan, Selangor, Malaysia and associated health risks
}

\author{
${ }^{1}$ Soong, A.C., ${ }^{1}$ Isa, N.M., ${ }^{1}$ Aris, A.Z., ${ }^{2}$ Haris, H. and ${ }^{1,{ }^{*}}$ Looi, L.J. \\ ${ }^{I}$ Department of Environment, Faculty of Forestry and Environment, Universiti Putra Malaysia, 43400 \\ UPM Serdang, Selangor, Malaysia \\ ${ }^{2}$ School of Biological Sciences, Universiti Sains Malaysia, 11800 Penang, Malaysia
}

\section{Article history:}

Received: 13 April 2020

Received in revised form: 19

May 2020

Accepted: 1 February 2021

Available Online: 21

February 2021

\section{Keywords:}

Estimated weekly intake, Health risk assessment,

Rice plant,

Total mercury

DOI:

https://doi.org/10.26656/fr.2017.5(S1).018

\begin{abstract}
Consumption of mercury-contaminated rice could pose a potential health risk to humans. In this study, total mercury $(\mathrm{THg})$ concentrations in various parts (roots, stems, leaves, and grains) of rice plant (Oryza sativa) collected from Sekinchan, Selangor, Malaysia were analysed for risk assessment. The THg concentrations in collected samples were analysed by Direct Mercury Analyzer (DMA-80). The mean concentrations found in plant parts were as follows: root, $47.01 \pm 0.42 \mu \mathrm{g} / \mathrm{kg}$; stem, $6.43 \pm 1.77 \mu \mathrm{g} / \mathrm{kg}$; leaf, $26.25 \pm 4.71$ $\mu \mathrm{g} / \mathrm{kg}$; grain, $2.64 \pm 0.42 \mu \mathrm{g} / \mathrm{kg}$. THg distribution in rice plants was roots $>$ leaves $>$ stems and grains. The mean THg concentration in grain $(2.64 \pm 0.42 \mu \mathrm{g} / \mathrm{kg})$ was below the maximum permitted proportion stipulated by Malaysian Food Regulation $1985(50.0 \mu \mathrm{g} /$ $\mathrm{kg}$ ). The estimated weekly intake (EWI) of THg through rice was $0.07 \pm 0.01 \mu \mathrm{g} / \mathrm{kg} \mathrm{bw} /$ week for $60 \mathrm{~kg}$ adult, below the provisional tolerable weekly intakes (PTWI) as suggested by JECFA indicating unlikely to cause impairment of public health due to consumption of rice planted in this region. However, periodical monitoring of mercury pollution in Selangor area is crucial because mercury contamination in crops could jeopardize food safety and security.
\end{abstract}

\section{Introduction}

Mercury $(\mathrm{Hg})$ contamination in agricultural crops has been regarded as an environmental problem affecting food safety and risking human health (Zhao et al., 2019). The understanding of $\mathrm{Hg}$ pollution status in an agricultural crop is essentially important as its health status is closely related to productivity, food safety, and human and ecosystem health (Aziz et al., 2015). Hg is a highly toxic pollutant that is capable to bioaccumulate and biomagnify across multiple trophic levels (Jan et al., 2015). The long-term ingestion of $\mathrm{Hg}$ contaminated rice as staple food could lead to the chronic neurotoxicity effects (Jackson, 2018). As population keep expanding, the increment of anthropogenic activities in mining, smelting and coal combustion has released $\mathrm{Hg}$ into the atmosphere, terrestrial and aquatic systems (Streets et al., 2019). Mercury can be transported globally (Kocman et al., 2017) and its distribution has been reported widely (Pacyna et al., 2010).

To date, Asia has become the main source of $\mathrm{Hg}$ emission, with east and southeast Asia countries contributed about $40 \%$ of the global total $\mathrm{Hg}$. Malaysia, among one of the developing countries in these regions, also faced mercury pollution (Habuer et al., 2016). Recent global anthropogenic $\mathrm{Hg}$ emissions estimated Malaysia released 6.13 tonnes, ranked at Top 5 among Southeast Asia countries (UNEP, 2018). Over the past decades, biomonitoring of $\mathrm{Hg}$ contamination was mainly focused on fish and seafood (Abeysinghe et al., 2017), which have been successful in creating awareness, especially pregnant women in the selection of seafoodbased dietary (Bloomingdale et al., 2010). In Malaysia, most of the $\mathrm{Hg}$ monitoring studies focused on river water, sediment, and fish and shellfish (Hajeb et al., 2012; Praveena et al., 2013; Looi et al., 2015). In recent year, $\mathrm{Hg}$ is also detected in tropical fruits such as papaya and mango (Praveena et al., 2013). However, little attention was paid on crop plant such as rice (Oryza sativa $\mathrm{L})$.

Plants can absorb $\mathrm{Hg}$ that is deposited on the leaf surface. It can also uptake $\mathrm{Hg}$ from water and soil via roots ( $\mathrm{Li}$ et al., 2017). In comparison to other crop plants, rice is known with greater ability to accumulate MeHg (Qiu et al., 2008). In Malaysia, the paddy plantation supplies $71 \%$ of rice to support the local 
market requirement (Ismail and Ngadiman, 2017). However, to date, there is no study investigating the $\mathrm{Hg}$ pollution status in Malaysian soil-rice system. Since rice is the staple food for most of the world including Malaysia, it is important to assess the health risk due to exposure of $\mathrm{Hg}$ via rice consumption. It is imperative to fill in this gap of knowledge to provide baseline data on $\mathrm{Hg}$ pollution status in rice plant for food safety and health risk assessment. The aims of this study are to (i) determine the $\mathrm{THg}$ concentration in various parts (roots, stems, leaves, and grains) of rice plant (Oryza sativa) collected from Sekinchan, Selangor, Malaysia, and (ii) preliminary assess the potential human health risk associated with $\mathrm{THg}$ exposure based on the maximum permitted proportion stipulated by Malaysian Food Regulation 1985 and estimated weekly intake (EWI).

\section{Materials and methods}

\subsection{Sampling sites}

Sekinchan, Selangor is well-known for its paddy plantation activities in Malaysia. Rice plants were collected randomly from five sampling sites in May 2019 (Table 1).

\subsection{Sampling and analytical procedure}

Rice plants were collected in triplicate and the collected samples were kept in the acid-washed ziplock polyethylene bags and transported to the laboratory at $<4^{\circ} \mathrm{C}$ for sample preparation and analysis. In the laboratory, the rice plants were homogenised according to sampling sites and rinsed with deionised water before divided the rice plants to its parts (i.e., root, stem, leaf, and grain). Subsequently, plant parts were oven-dried at $50^{\circ} \mathrm{C}$ until a constant weight was achieved, followed by grinding, manual husk separation, and sieved through 1 $\mathrm{mm}$ mesh sieve (Juen et al., 2014). About $0.2 \mathrm{~g}$ of prepared samples were weighted and introduced in direct mercury analyser (DMA-80, Milestone, CT, USA) for $\mathrm{THg}$ determination. The limit of detection (LOD) and limit of quantification (LOQ) for $\mathrm{THg}$ analysis were 0.01 and $0.04 \mathrm{ng}$, respectively.

\subsection{Quality assurance and quality control (QA/QC)}

Homogenized and triplicate $(\mathrm{n}=3)$ samples were collected from each sampling sites to address the variability due to sampling activities. Besides, triplicate readings and relative standard deviation were taken to ensure representative results. Method and standard blanks were used to account for background correction. The analytical method was verified using by the analysis of standard reference material (NIST-SRM 1568b: Rice Flour). The average THg recovery for SRM $1568 \mathrm{~b}$ was $83.4 \%$.

\subsection{THg weekly intake for Malaysian}

The calculation of the estimated weekly intake (EWI) for $\mathrm{THg}$ was based on the average rice consumption for residents in Malaysia at $87.64 \mathrm{~kg} / \mathrm{capita} /$ year (OECD-FAO, 2019). This is equivalent to $1.68 \mathrm{~kg} /$ capita/week. The EWI for THg of an adult weighing 60 $\mathrm{kg}$ was estimated as follow:

THg EWI $(\mu \mathrm{g} / \mathrm{kg})=[$ rice consumption $(\mathrm{kg} /$ week $) \times$ rice $\mathrm{THg}$ concentration $(\mu \mathrm{g} / \mathrm{kg}) / 60 \mathrm{~kg}$ ]

The EWI was compared with provisional tolerable weekly intakes (PTWI) as suggested by the Joint FAO/ WHO Expert Committee on Food Additives (JECFA).

\subsection{Statistical analysis}

Data collected were analysed using IBM SPSS Statistics 23 software. One-way analysis of variance (ANOVA) was used to determine whether there was a significant difference between various parts of the rice plant.

\section{Results and discussion}

\subsection{THg in rice plant}

The THg concentration in rice plant parts was below the maximum permitted proportion set by Malaysian Food Regulation 1985 (Ministry of Health Malaysia, 2006), except for roots from sampling sites P1 and P2 (Table 2). The higher concentration in roots indicating the uneven spatial distribution of mercury in soil (Huang et al., 2019), atmosphere, and groundwater

Table 1. The description of sampling sites from Sekinchan, Selangor

\begin{tabular}{|c|c|c|c|}
\hline No & Abbreviation & GPS & Site Description \\
\hline 1 & $\mathrm{P} 1$ & $\begin{array}{l}3^{\circ} 31^{\prime} 21.066^{\prime \prime} \mathrm{N} \\
101^{\circ} 66^{\prime} 53.46^{\prime \prime} \mathrm{E}\end{array}$ & Paddy field near a temporary paddy storage area \\
\hline 2 & $\mathrm{P} 2$ & $\begin{array}{l}3^{\circ} 30^{\prime} 2.94^{\prime \prime} \mathrm{N} \\
101^{\circ} 77^{\prime} 32.52^{\prime \prime} \mathrm{E}\end{array}$ & Paddy field beside the river water intake point \\
\hline 3 & P3 & $\begin{array}{l}3^{\circ} 30^{\prime} 3.18^{\prime \prime} \mathrm{N} \\
101^{\circ} 7{ }^{\prime} 32.82^{\prime \prime} \mathrm{E}\end{array}$ & Paddy field beside the river water intake point, separated by a short walkway from $\mathrm{P} 2$ \\
\hline 4 & $\mathrm{P} 4$ & $\begin{array}{l}3^{\circ} 30^{\prime} 22.32^{\prime \prime} \mathrm{N} \\
101^{\circ} 8{ }^{\prime} 1.68^{\prime \prime} \mathrm{E}\end{array}$ & Paddy field beside the river water intake point \\
\hline 5 & P5 & $\begin{array}{l}3^{\circ} 31^{\prime} 10.62^{\prime \prime} \mathrm{N} \\
101^{\circ} 8 \text { 8'0.90’"E }\end{array}$ & Paddy field near paddy processing plant \\
\hline
\end{tabular}


contamination caused by nearby active landfills. This study found that the $\mathrm{THg}$ differed significantly in the parts of rice plants $(p<0.05)$ except for stems and grains. The mean $\mathrm{THg}$ concentration in various parts of rice plant in descending order: root $(47.01 \pm 0.42 \mu \mathrm{g} / \mathrm{kg})>$ leaf $(26.25 \pm 4.71 \mu \mathrm{g} / \mathrm{kg})>$ stem $(6.43 \pm 1.77 \mu \mathrm{g} / \mathrm{kg})$ and grain $(2.64 \pm 0.42 \mu \mathrm{g} / \mathrm{kg}$ ) (Figure 1). The THg distributions in rice plant parts are similar to those reported in by Pang et al. (2019) but inconsistent with the THg distributions in rice plant (leaf $>$ root $>$ stem $>$ grain) cultivated in Xinyang city, China, which has low background soil THg level (Tang et al., 2017). Previous studies suggested that $\mathrm{Hg}$ concentrations in rice root were correlated with Hg concentrations in soil (Meng et al., 2014; Tang et al., 2017). Thus, the relatively high $\mathrm{THg}$ concentration in root compared to other rice plant parts $(p<0.05)$ indicating $\mathrm{THg}$ might originate from the soil. In addition to bioaccumulation pathway, the plant is also capable to absorb atmospheric mercury via leaf and stem (Pang et al., 2019).

Table 2. Total mercury ( $\mathrm{THg}$ ) concentrations $(\mu \mathrm{g} / \mathrm{kg})$ of rice plant parts compared with maximum permitted proportion as stipulated by Malaysian Food Regulation 1985

\begin{tabular}{cccc}
\hline Sampling site & Plant parts & Mean & Standard Deviation \\
\hline \multirow{4}{*}{ P1 } & Root & 70.88 & 6.83 \\
& Stem & 9.48 & 0.7 \\
& Leaves & 34.02 & 2.56 \\
& Grain & 2.25 & 0.2 \\
\hline \multirow{4}{*}{ P2 } & Root & 52.86 & 3.45 \\
& Stem & 5.01 & 0.58 \\
& Leaves & 27.41 & 2.35 \\
& Grain & 3.04 & 0.13 \\
\hline \multirow{4}{*}{ P3 } & Root & 37.16 & 2.91 \\
& Stem & 6.3 & 0.36 \\
& Leaves & 23.51 & 0.59 \\
P4 & Grain & 2.29 & 0.19 \\
\hline & Root & 41.5 & 2.59 \\
& Stem & 5.78 & 1.25 \\
& Leaves & 22.82 & 0.51 \\
P5 & Grain & 2.47 & 0.08 \\
\hline & Root & 32.67 & 1.63 \\
& Stem & 5.6 & 0.31 \\
& Leaves & 23.47 & 1.08 \\
& Grain & 3.15 & 0.15 \\
\hline
\end{tabular}

Maximum permitted proportion $^{\mathrm{a}} \quad 50$

${ }^{a}$ Malaysian Food Regulation 1985 (Regulation 38, Fourteenth Schedule)

\subsection{Estimated weekly intake}

The estimated weekly intake (EWI) of THg from the consumption of rice by an adult of $60 \mathrm{~kg}$ was $0.07 \pm 0.01$ $\mu \mathrm{g} / \mathrm{kg}$ body weight. The EWI was remarkably below the provisional tolerable weekly intake (PTWI) of $4 \mu \mathrm{g} / \mathrm{kg}$ body weight as suggested by Joint FAO/WHO Expert

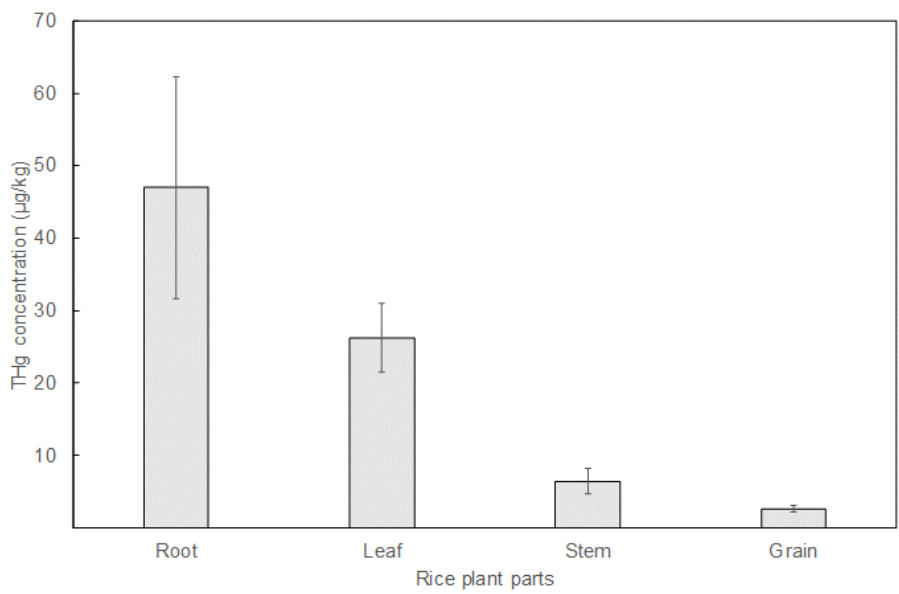

Figure 1. Total mercury (THg) concentrations $(\mu \mathrm{g} / \mathrm{kg})$ of rice plant parts collected from Sekinchan, Selangor

Committee on Food Additives (JECFA, 2011), suggesting that the exposure of THg due to consumption of rice grown in sampling sites would unlikely to cause public health implication. Even though the EWIs from this study were far below the PTWI issued by the JECFA, future monitoring studies emphasis on assessing the 'true' health effects of THg exposure in the local rice -consumption population, especially on pregnant women and children which are the vulnerable groups are needed. A detailed social study that takes demographic parameters such as gender, age, occupational, and educational status into account should be incorporated in the abovementioned monitoring study.

\section{Conclusion}

In general, the $\mathrm{THg}$ concentrations were higher in the root of the rice plant, followed by leaf, stem, and grain. Notably, the concentrations of $\mathrm{THg}$ in rice grains were below the maximum permitted proportion set by Malaysian Food Regulation 1985 and PTWI recommended by JECFA. Although the rice grain has a relatively low level of $\mathrm{THg}$, it is clearly shown that rice can accumulate THg. Therefore, periodic monitoring and assessing the health risk associated with mercury exposure, especially concerning the most toxic methylmercury, should be carried out in order to safeguard food security.

\section{Acknowledgement}

The authors would like to acknowledge the financial support provided by Universiti Putra Malaysia (GPIPM/2019/9679100).

\section{References}

Abeysinghe, K.S., Qiu, G.L, Goodale, E., Anderson, C.W.N., Bishop, K., Evers, D.C., Goodale, M.W., Hintelmann, H., Liu, S.J., Mammides, C., Quan, R.C., Wang, J., Wu, P.P., Xu, X.H., Yang, X.D. and 
Feng, X. (2017). Mercury flow through an Asian rice -based food web. Environmental Pollution, 229, 219228. https://doi.org/10.1016/j.envpol.2017.05.067

Aziz, R.A., Rahim, S.A., Sahid, I., Idris, W.M.R. and Bhuiyan, M.A.R. (2015). Determination of heavy metals uptake in soil and paddy plants. AmericanEurasian Journal of Agricultural and Environmental Sciences, 15(2), 161-164.

Bloomingdale, A., Guthrie, L.B., Price, S., Wright, R.O., Platek, D., Haines, J. and Oken, E. (2010). A qualitive study of fish consumption during pregnancy. The American Journal of Clinical Nutrition, 95(5), 1234-1240. https://doi.org/10.3945/ ajen.2010.30070

Ministry of Health Malaysia. (2006). Food Act 1983 Act (281) and Regulations-Law of Malaysia. Petaling Jaya, Selangor: International Law Book Services.

Habuer, Yoshimoto, N., Takaoka, M., Fujimori, T., Oshita, K., Sakai, N. and Abd Kdir, S.A. (2016). Substance flow analysis of mercury in Malaysia. Atmospheric Pollution Research, 7(5), 799-807. https://doi.org/10.1016/j.apr.2016.04.005

Hajeb, P., Jinap, S., Ismail, A. and Mahyudin, N.A. (2012). Mercury pollution in Malaysia. In Whitacre, D.M. (Ed.), Reviews of Environmental Contamination and Toxicology, p. 45-66. New York, USA: Springer. https://doi.org/10.1007/978-1-46143414-6_2

Huang, Y., Wang, L., Wang, W., Li, T., He, Z. and Yang, X. (2019). Current status of agricultural soil pollution by heavy metals in China: A meta-analysis. Science of the Total Environment, 651(Part 2), 30343042. https://doi.org/10.1016/j.scitotenv.2018.10.185

Ismail, W.I.F.W. and Ngadiman, N. (2017). Land use conversion on rice production: policies, rice productivity and paddy landowners. International Journal of Real Estate Studies, 11(2), 35-39.

Jackson, A.C. (2018). Chronic neurological disease due to methylmercury poisoning. Canadian Journal of Neurological Sciences, 45(6), 620-623. https:// doi.org/10.1017/cjn.2018.323

Jan, A.T., Azam, M., Siddiqui, K., Ali, A., Choi, I. and Haq, Q.M.R. (2015). Heavy metals and human health: mechanistic insight into toxicity and counter defense system of antioxidants. International Journal of Molecular Sciences, 16(12), 1959229630. https://doi.org/10.3390/ijms161226183

JECFA. (2011). Evaluation of certain food additives and contaminants. 72nd Report of the Joint FAO/WHO Expert Committee on Food Additives. WHO Technical ReportSeries 959. Geneva, Switzerland: WHO.
Juen, L.L., Aris, A.Z., Lim, W.Y. and Haris, H. (2014). Bioconcentration and translocation efficiency of metals in paddy (Oryza sativa): A case study from Alor Setar, Kedah, Malaysia. Sains Malaysiana, 43 (4), 521-528.

Kocman, D., Wilson, S.J., Amos, H.M., Telmer, K.H., Steenhuisen, F., Sunderland, E.M., Manson, R.P., Outridge, P. and Horvat, M. (2017). Toward an assessment of the global inventory of present-day mercury releases to freshwater environments. International Journal of Environmental Research and Public Health, 14(2), $138 . \quad \mathrm{https} / /$ doi.org/10.3390/ijerph14020138

Li, R., Wu, H., Ding, J., Fu., W., Gan, L. and Li, Y. (2017). Mercury pollution in vegetables, grains and soils from areas surrounding coal-fired power plants. Scientific Reports, 7, 46545. https://doi.org/10.1038/ srep46545

Looi, L.J., Aris, A.Z., Yusoff, F.M. and Hashim, Z. (2015). Mercury contamination in the estuaries and coastal sediments of the Strait of Malacca. Environmental monitoring and assessment, 187(1), 4099. https://doi.org/10.1007/s10661-014-4099-5

Meng, M., Li, B., Shao, J., Wang, T., He, B., Shi, J., Ye, Z. and Jiang, G. (2014). Accumulation of total mercury and methylmercury in rice plants collected from different mining areas in China. Environmental Pollution, 184, 179-186. https://doi.org/10.1016/ j.envpol.2013.08.030

OECD-FAO. (2019). Agricultural Outlook (2017 2028). Retrieved from OECD website: https:// stats.oecd.org/viewhtml.aspx?

QueryId $=91991 \& \mathrm{vh}=0000 \& v f=0 \& 1 \& i l=\&$ lang=en

Pacyna, E.G., Pacyna, J.M., Sundseth, K., Munthe, J., Kindbom, K., Wilson, S., Steenhuisen, F. and Maxson, P. (2010). Global emission of mercury to the atmosphere from anthropogenic sources in 2005 and projections to 2020. Atmospheric Environment, 44(20), 2487-2499. https://doi.org/10.1016/ j.atmosenv.2009.06.009

Pang, J., Han, J., Fan, X., Li, C., Dong, X., Liang, L. and Chen, Z. (2019). Mercury speciation, bioavailability and risk assessment on soil-rice systems from a watershed impacted by abandoned $\mathrm{Hg}$ Mine-waste tailings. Acta Geochim, 38(3),391-403. https:// doi.org/10.1007/s11631-018-0305-4

Praveena, S.M., de Burbure, C., Aris, A.Z. and Hashim, Z. (2013). Mini review of mercury contamination in environment and human with an emphasis on Malaysia: status and needs. Reviews on Environmental Health, 28(4), 195-202. https:// doi.org/10.1515/reveh-2013-0011

Qiu, G., Feng, X., Li, P., Wang, S., Li, G., Shang, L. and 
Fu, X. (2008). Methylmercury Accumulation in Rice (Oryza sativa L.) Grown at Abandoned Mercury Mines in Guizhou, China. Journal of Agricultural and Food Chemistry, 56(7), 2465-2468. https:// doi.org/10.1021/jf073391a

Streets, D.G., Horowitz, H.M., Lu, Z., Levin, L., Thackray, C.P. and Sunderland, E.M. (2019). Five hundred years of anthropogenic mercury: spatial and temporal release profiles. Environmental Research Letters, 14, 084004. https://doi.org/10.1088/17489326/ab281f

Tang, S., Fan, H., Mao, T. and Huang, Z. (2017). Methylmercury accumulation in rice plants (Oryza sativa L.) in low $\mathrm{Hg}$ areas and the potential health risk exposing in extreme micro-environments. Advanced Materials Science, 2(3), 1-6. https:// doi.org/10.15761/AMS.1000129

UNEP (United Nations Environment Programme). (2018). Global mercury assessment. Retrieved in February 2019 from UNEP website: https:// www.unenvironment.org/explore-topics/chemicalswaste/what-we-do/mercury/global-mercuryassessment.

Zhao, H., Yan, H., Zhang, L., Sun, G., Li, P. and Feng, X. (2019). Mercury contents in rice and potential health risks across China. Environment International, 126, 406-412. https://doi.org/10.1016/ j.envint.2019.02.055 